\title{
Inheritance of Resistance to Bacterial Blight in 21 Cultivars of Rice
}

\author{
K. S. Lee, S. Rasabandith, E. R. Angeles, and G. S. Khush
}

International Rice Research Institute, DAPO Box 7777, Metro Manila, Philippines.

Accepted for publication 6 September 2002.

\begin{abstract}
Lee, K. S., Rasabandith, S., Angeles, E. R., and Khush, G. S. 2003. Inheritance of resistance to bacterial blight in 21 cultivars of rice. Phytopathology 93:147-152.

Genetic analysis for resistance to bacterial blight (Xanthomonas oryzae pv. oryzae) of 21 rice (Oryza sativa L.) cultivars was carried out. These cultivars were divided into two groups based on their reactions to Philippine races of bacterial blight. Cultivars of group 1 were resistant to race 1 and those of group 2 were susceptible to race 1 but resistant to race 2 . All the cultivars were crossed with $\mathrm{TN} 1$, which is susceptible to all the Philippine races of $X$. oryzae pv. oryzae. $\mathrm{F}_{1}$ and $\mathrm{F}_{2}$ populations of hybrids of group 1 cultivars were evaluated using race 1 and $F_{1}$ and $F_{2}$ populations of hybrids of group 2 cultivars were evaluated using race 2 . All the cultivars showed monogenic inheritance of resistance. Allelic re-

lationships of the genes were investigated by crossing these cultivars with different testers having single genes for resistance. Three cultivars have $X a 4$, another three have $x a 5$, one has $x a 8$, two have $X a 3$, eight have $\mathrm{Xa10}$, and one has $\mathrm{Xa} 4$ as well as $\mathrm{Xa10}$. Three cultivars have new, as yet undescribed, genes. Nep Bha Bong To has a new recessive gene for moderate resistance to races 1,2 , and 3 and resistance to race 5 . This gene is designated $x a 26(t)$. Arai Raj has a dominant gene for resistance to race 2 which segregates independently of $\mathrm{Xa10}$. This gene is designated as $X a 27(t)$. Lota Sail has a recessive gene for resistance to race 2 which segregates independently of $\mathrm{Xa10}$. This gene is designated as $x a 28(t)$.

Additional keywords: durable resistance, genetic engineering, independent segregation, isogenic lines, marker aided selection, molecular markers, pyramided lines.
\end{abstract}

Bacterial blight, caused by Xanthomonas oryzae pv. oryzae, is one of the most serious diseases of rice. It is widespread throughout Asia and also has been reported to occur in Australia, the United States, and several rice-growing countries of Latin America and Africa (16). The disease may cause damage at seedling stage resulting in complete wilting or death of affected tillers. The infection at maximum tillering stage results in blighting of leaves. The yield losses in severely infected fields generally range from 20 to $30 \%$ but may reach up to $80 \%(24,28)$.

Chemical control of bacterial blight in the monsoon climate of Asia is impractical. Additionally, no effective bactericide is commercially available for disease control. Therefore, the preferred strategy for disease management is through varietal resistance. Large germ plasm collections have been screened to identify sources of resistance for breeding programs and many resistant cultivars have been genetically analyzed to identify diverse genes for resistance. To date, 22 genes for resistance have been identified $(2,3,11,12,15,23,25-27,34)$. Two of the genes, Xal and Xa21, have been cloned $(30,33)$. Several of these genes have been incorporated into improved rice cultivars which are now widely grown (14). However, new races of the pathogen continue to evolve that can overcome the resistance conveyed by the major genes $(16,19)$.

Mew and Vera Cruz (17) reported four races of bacterial blight in the Philippines and Vera Cruz and Mew (32) reported six races. Two additional races were described by Nelson et al. (21). Some of these races may have originated as a result of deployment of cultivars with major genes. Others may have existed but were identified when additional differentials were employed. In order to maintain a dynamic breeding program for bacterial blight resis-

Corresponding author: G. S. Khush; E-mail address: G.Khush@cgiar.org

Publication no. P-2002-1125-01R

(C) 2003 The American Phytopathological Society tance for such a variable pathogen, a constant supply of new genes is needed. This study was undertaken to identify additional genes for resistance to bacterial blight.

\section{MATERIALS AND METHODS}

Twenty-one rice cultivars were analyzed (Table 1). These cultivars were divided into two groups based on their reaction to $X$. oryzae pv. oryzae. Cultivars of group 1 are resistant to Philippine race 1 and a few other races. Cultivars of group 2 are susceptible to race 1 but resistant to races 2 and 5. This division is important because two genes, $\mathrm{Xa} 4$ and $x a 5$, which are commonly found in resistant cultivars, convey resistance to races 1 and 5. On the other hand, cultivars susceptible to race 1 but resistant to races 2 and 5 have $\mathrm{XalO}$ for resistance. Seven testers were employed for genetic analysis (Table 2). These lines included six isogenic lines with single genes for resistance and $\mathrm{TN} 1$, which is susceptible to all Philippine races of $X$. oryzae $p v$. oryzae.

All the cultivars were crossed with $\mathrm{TN} 1 . \mathrm{F}_{1}$ and $\mathrm{F}_{2}$ populations from the crosses of group 1 cultivars were inoculated with race 1 , whereas the $F_{1}$ and $F_{2}$ populations from the crosses of group 2 cultivars were inoculated with race 2 . The gene for resistance of each cultivar was predicted on the basis of their reaction pattern to six Philippine races of bacterial blight. Thereafter, the test cultivars were crossed with various testers having the known genes for resistance to verify our predictions.

The inoculation method of Kauffman et al. (9) was employed for inoculation of hybrid progenies. Pure cultures of the bacterial strains were maintained in the bacterial blight laboratory at the Plant Breeding, Genetics, and Biochemistry Division, International Rice Research Institute (IRRI). The inoculum was prepared and diluted by mixing bacterial cultures in distilled water. Using a spectrophotometer, the absorbance $(A)$ of the inoculum was adjusted to $A=0.05(620 \mathrm{~nm})$. This value corresponds to a concentration of $\approx 10^{8}$ cells per $\mathrm{ml}$. Plants were inoculated at 
maximum tillering (40 days after transplanting) or booting stage (55 to 60 days after transplanting) and were scored for disease reaction 14 days after inoculation. Both visual assessment and lesion length measurements of three inoculated leaves of at least three plants of each $F_{1}$ population were carried out. Each plant of $\mathrm{F}_{2}$ populations was classified visually as either resistant (lesion length $<10 \mathrm{~cm}$ ) or susceptible (lesion length $>10 \mathrm{~cm}$ ).

\section{RESULTS}

Inheritance of resistance. The reactions to race 1 of $F_{1}$ and $F_{2}$ populations of crosses of group 1 cultivars with TN1 are given in Table 3. The $F_{1}$ hybrids of cvs. Bazail 975, Karia, Minh-Soc, Nep Bha Bong To, and Latu were susceptible and their $F_{2}$ populations segregated in a ratio of one resistant to three susceptible, indicating monogenic recessive control of resistance in these cultivars. The $F_{1}$ hybrids of cvs. WC1263, HR 12, SLO 2, Ragu Sail, Trang Chum, and $\mathrm{Ba}$ Kieu were resistant and their $\mathrm{F}_{2}$ populations segregated in a ratio of three resistant to one susceptible, indicating that each of them have a dominant gene for resistance to race 1 .

The reactions to race 2 of $F_{1}$ and $F_{2}$ populations of crosses of group 2 cultivars with TN1 are given in Table 4 . The $\mathrm{F}_{1}$ hybrids of all cultivars except Lota Sail were resistant and $F_{2}$ populations segregated in a ratio of three resistant to one susceptible, indicating monogenic dominant control of resistance to race 2 in these cultivars. The $F_{1}$ hybrid of Lotal Sail with TN1 was susceptible and the $F_{2}$ population segregated in a ratio of one resistant to three susceptible, indicating Lota Sail has a recessive gene for resistance to race 2 .

SLO 2 also showed resistance to race 2 ; therefore, the $F_{1}$ and $F_{2}$ populations of its cross with TN1 also were evaluated for resistance to race 2 (Table 4). The $F_{1}$ hybrid was resistant, and the $F_{2}$ population segregated in a ratio of three resistant to one susceptible, indicating that it has a dominant gene for resistance to race 2 .

Allele tests. WC1263, HR 12, and Ragu Sail have the reaction pattern to six races typical of rice cultivars with $\mathrm{Xa4}$; therefore, these cultivars were crossed with IRBB4. SLO 2 also was crossed with IRBB4 to determine if its resistance to race 1 may also be due to $\mathrm{Xa}$ 4. The $\mathrm{F}_{1}$ hybrids of these four crosses were resistant to race 1 , and the $F_{2}$ population did not segregate for susceptibility, showing that resistance to race 1 in these cultivars is due to $\mathrm{Xa4}$ (Table 5).

The reaction pattern of Bazail 975, Karia, and Latu to six races was similar to that of cultivars with $x a 5$ (i.e., resistant to races 1 , 2, 3, and 5 and susceptible to races 4 and 6). Therefore, these cultivars were crossed with IRBB5. The $\mathrm{F}_{1}$ hybrids were resistant to race 1 and $F_{2}$ populations did not segregate for susceptibility (Table 5), showing that these three cultivars have $x a 5$ for resistance.

Trang Chum and $\mathrm{Ba}$ Kieu were found to have a dominant gene for resistance to race 1 , and their reaction pattern to six races was similar to that of cultivars with $\mathrm{Xa3}$ (i.e., moderately resistant to races 1,2 , and 3 , resistant to race 5 , and susceptible to races 4 and 6 ); therefore, they were crossed with IRBB3. The $F_{1}$ hybrids were resistant to race 1 and $F_{2}$ populations did not segregate for susceptibility. These results show that Trang Chum and Ba Kieu have Xa3 for resistance (Table 5).

Minh-Soc and Nep Bha Bong To were found to have a recessive gene for resistance to race 1 and their reaction pattern was similar to that of $x a 8$ to six races; therefore, they were crossed with IRBB8. Nep Bha Bong To showed segregation with IRBB8, so it also was crossed with IRBB5. The $\mathrm{F}_{1}$ hybrid of Minh-Soc with IRBB8 was resistant and the $F_{2}$ population did not segregate for susceptibility (Table 5). These results indicate that Minh-Soc has $x a 8$ for resistance. The $\mathrm{F}_{1}$ hybrids of Nep Bha Bong To with IRBB5 and IRBB8 were susceptible and the $F_{2}$ populations

TABLE 2. Reactions of various testers to the six Philippine races of Xanthomonas oryzae pv. oryzae

\begin{tabular}{llllllll}
\hline & & \multicolumn{6}{c}{ Reaction to race $^{\mathrm{a}}$} \\
\cline { 4 - 8 } Tester & Gene & & \multicolumn{6}{c}{ 1 } & 2 & 3 & 4 & 5 & 6 \\
\hline TN1 & $\ldots$ & $\mathrm{S}$ & $\mathrm{S}$ & $\mathrm{S}$ & $\mathrm{S}$ & $\mathrm{S}$ & $\mathrm{S}$ \\
IRBB3 & Xa3 & $\mathrm{MR}$ & $\mathrm{MR}$ & $\mathrm{MR}$ & $\mathrm{S}$ & $\mathrm{R}$ & $\mathrm{S}$ \\
IRBB4 & Xa4 & $\mathrm{R}$ & $\mathrm{S}$ & $\mathrm{S}$ & $\mathrm{S}$ & $\mathrm{R}$ & $\mathrm{S}$ \\
IRBB5 & $x a 5$ & $\mathrm{R}$ & $\mathrm{R}$ & $\mathrm{R}$ & $\mathrm{S}$ & $\mathrm{R}$ & $\mathrm{S}$ \\
IRBB7 & Xa7 & $\mathrm{MR}$ & $\mathrm{R}$ & $\mathrm{R}$ & $\mathrm{S}$ & $\mathrm{R}$ & $\mathrm{S}$ \\
IRBB8 & $x a 8$ & $\mathrm{MR}$ & $\mathrm{MR}$ & $\mathrm{MR}$ & $\mathrm{S}$ & $\mathrm{R}$ & $\mathrm{S}$ \\
IRBB10 & Xa10 & $\mathrm{S}$ & $\mathrm{R}$ & $\mathrm{S}$ & $\mathrm{S}$ & $\mathrm{R}$ & $\mathrm{S}$ \\
\hline
\end{tabular}

${ }^{a} \mathrm{R}=$ resistant, $\mathrm{MR}=$ moderately resistant, and $\mathrm{S}=$ susceptible.

TABLE 1. Rice cultivars used in the study and their reactions to the six Philippine races of Xanthomonas oryzae pv. oryzae

\begin{tabular}{|c|c|c|c|c|c|c|c|c|}
\hline \multirow[b]{2}{*}{ Cultivar } & \multirow[b]{2}{*}{ Accession no. ${ }^{b}$} & \multirow[b]{2}{*}{ Origin } & \multicolumn{6}{|c|}{ Reaction to $X$. oryzae pv. oryzae races ${ }^{\mathrm{a}}$} \\
\hline & & & 1 & 2 & 3 & 4 & 5 & 6 \\
\hline \multicolumn{9}{|l|}{ Group 1} \\
\hline WC1263 & 11057 & India & $\mathrm{R}$ & $\mathrm{S}$ & $\mathrm{S}$ & $\mathrm{S}$ & $\mathrm{R}$ & $\mathrm{S}$ \\
\hline HR 12 & 674 & India & $\mathrm{R}$ & $\mathrm{S}$ & $\mathrm{S}$ & $\mathrm{S}$ & $\mathrm{R}$ & $\mathrm{S}$ \\
\hline SLO 2 & 678 & India & $\mathrm{R}$ & $\mathrm{R}$ & $\mathrm{S}$ & $\mathrm{S}$ & $\mathrm{R}$ & $\mathrm{S}$ \\
\hline Ragu Sail & 26774 & Bangladesh & $\mathrm{R}$ & $\mathrm{S}$ & $\mathrm{S}$ & $\mathrm{S}$ & $\mathrm{R}$ & $\mathrm{S}$ \\
\hline Bazail 975 & 32816 & Bangladesh & $\mathrm{R}$ & $\mathrm{R}$ & $\mathrm{R}$ & $\mathrm{S}$ & $\mathrm{R}$ & $\mathrm{S}$ \\
\hline Karia & 6702 & Fiji & $\mathrm{R}$ & $\mathrm{R}$ & $\mathrm{R}$ & $\mathrm{S}$ & $\mathrm{R}$ & $S$ \\
\hline Latu & 18093 & Indonesia & $\mathrm{R}$ & $\mathrm{R}$ & $\mathrm{R}$ & $\mathrm{S}$ & $\mathrm{R}$ & $\mathrm{S}$ \\
\hline Minh-Soc & 16731 & Vietnam & MR & MR & MR & $\mathrm{S}$ & $\mathrm{R}$ & $\mathrm{S}$ \\
\hline Trang Chum & 16778 & Vietnam & MR & MR & MR & $\mathrm{S}$ & $\mathrm{R}$ & $\mathrm{S}$ \\
\hline Ba Kieu & 16855 & Vietnam & MR & MR & MR & $\mathrm{S}$ & $\mathrm{R}$ & $S$ \\
\hline Nep Bha Bong To & 17005 & Vietnam & MR & MR & MR & $\mathrm{S}$ & $\mathrm{R}$ & $\mathrm{S}$ \\
\hline \multicolumn{9}{|l|}{ Group 2} \\
\hline Aghanisail & 25827 & Bangladesh & $\mathrm{S}$ & $\mathrm{R}$ & $\mathrm{S}$ & $\mathrm{S}$ & $\mathrm{R}$ & $\mathrm{S}$ \\
\hline Arai Raj & 26536 & Bangladesh & $\mathrm{S}$ & $\mathrm{R}$ & $\mathrm{S}$ & $\mathrm{S}$ & $\mathrm{R}$ & $\mathrm{S}$ \\
\hline Huson Dhaw & 26644 & Bangladesh & $\mathrm{S}$ & $\mathrm{R}$ & $\mathrm{S}$ & $\mathrm{S}$ & $\mathrm{R}$ & $\mathrm{S}$ \\
\hline Khar Mao & 26687 & Bangladesh & $\mathrm{S}$ & $\mathrm{R}$ & $\mathrm{S}$ & $\mathrm{S}$ & $\mathrm{R}$ & $\mathrm{S}$ \\
\hline Lota Sail & 26719 & Bangladesh & $\mathrm{S}$ & $\mathrm{R}$ & $\mathrm{S}$ & $\mathrm{S}$ & $\mathrm{R}$ & $S$ \\
\hline Pelatie & 30598 & Sierra Leone & $\mathrm{S}$ & $\mathrm{R}$ & $\mathrm{S}$ & $\mathrm{S}$ & $\mathrm{R}$ & $\mathrm{S}$ \\
\hline Ganga Sagar & 31650 & Bangladesh & $\mathrm{S}$ & $\mathrm{R}$ & $\mathrm{S}$ & $\mathrm{S}$ & $\mathrm{R}$ & S \\
\hline Bhua Balam & 31729 & Bangladesh & $\mathrm{S}$ & $\mathrm{R}$ & $\mathrm{S}$ & $\mathrm{S}$ & $\mathrm{R}$ & $\mathrm{S}$ \\
\hline Kanchanchari & 31837 & Bangladesh & $\mathrm{S}$ & $\mathrm{R}$ & $\mathrm{S}$ & $\mathrm{S}$ & $\mathrm{R}$ & $\mathrm{S}$ \\
\hline Surma Sail & 31941 & Bangladesh & $\mathrm{S}$ & $\mathrm{R}$ & $\mathrm{S}$ & $\mathrm{S}$ & $\mathrm{R}$ & S \\
\hline
\end{tabular}

${ }^{\text {a }} \mathrm{R}=$ resistant, $\mathrm{MR}=$ moderately resistant, and $\mathrm{S}=$ susceptible.

${ }^{\mathrm{b}}$ International Rice Research Institute accession numbers. 
segregated in a ratio of seven resistant to nine susceptible (Table 5). These results show that the recessive gene for resistance to race 1 of Nep Bha Bong To is nonallelic to and independent of $x a 5$ and $x a 8$.

Eleven cultivars of group 2 showed a reaction pattern to six races that is similar to that of IRBB10 (i.e., resistance to races 2 and 5 but susceptible to races 1,3, 4, and 6). These 11 cultivars were crossed with IRBB10. The $F_{2}$ population of Arai Raj from its cross with IRBB10 segregated for susceptibility; therefore, it also was crossed with IRBB7. Genetic analysis indicated that Lota Sail has a recessive gene for resistance to race 2, so it also was crossed with IRBB5 and IRBB8. The $\mathrm{F}_{1}$ hybrids of SLO 2, Aghanisail, Huson Dhaw, Pelatie, Bhua Balam, Kanchanchari, Surma Sail,
Khar Mao, and Ganga Sagar with IRBB10 were resistant and $\mathrm{F}_{2}$ populations did not segregate for susceptibility (Table 6). These results show that these nine cultivars have $\mathrm{XalO}$ for resistance to race 2 .

The $\mathrm{F}_{2}$ populations of Arai Raj with IRBB10 and IRBB7 segregated in a ratio of 15 resistant to 1 susceptible, indicating that the dominant gene of Arai Raj for resistance to race 2 is different from and independent of $\mathrm{Xa10}$ and $\mathrm{Xa}$. The $\mathrm{F}_{2}$ populations of Lota Sail from crosses with IRBB10, IRBB5, and IRBB8 segregated in resistant:suspectible ratios of 13:3, 7:9, and 7:9, respectively. These data indicate that the recessive gene of Lota Sail for resistance to race 2 is different from and independent of $\mathrm{Xa10}$ as well as $x a 5$ and $x a 8$.

TABLE 3. Reaction of $\mathrm{F}_{1}$ hybrids and $\mathrm{F}_{2}$ populations to race 1 of Xanthomonas oryzae pv. oryzae from crosses of group 1 cultivars with susceptible cv. TN1

\begin{tabular}{|c|c|c|c|c|c|c|}
\hline \multirow[b]{3}{*}{ Cross } & \multicolumn{6}{|c|}{ Reaction to race $1^{\mathrm{a}}$} \\
\hline & \multirow[b]{2}{*}{$\mathrm{F}_{1}$ plants } & \multicolumn{5}{|c|}{$\mathrm{F}_{2}$ population } \\
\hline & & $\mathrm{R}$ & $\mathrm{S}$ & Ratio & $\chi^{2}$ & $P$ value \\
\hline $\mathrm{TN} 1 \times \mathrm{WC} 1263$ & $\mathrm{R}$ & 284 & 92 & $3: 1$ & 0.06 & $0.75-0.90$ \\
\hline $\mathrm{TN} 1 \times \mathrm{HR} 12$ & $\mathrm{R}$ & 298 & 110 & $3: 1$ & 0.84 & $0.25-0.50$ \\
\hline $\mathrm{TN} 1 \times \mathrm{SLO} 2$ & $\mathrm{R}$ & 274 & 87 & $3: 1$ & 0.16 & $0.50-0.75$ \\
\hline TN1 × Ragu Sail & $\mathrm{R}$ & 311 & 116 & $3: 1$ & 1.07 & $0.25-0.50$ \\
\hline TN1 $\times$ Bazail 975 & $\mathrm{~S}$ & 123 & 351 & $1: 3$ & 0.23 & $0.50-0.75$ \\
\hline $\mathrm{TN} 1 \times$ Karia & $\mathrm{S}$ & 91 & 228 & $1: 3$ & 2.11 & $0.10-0.25$ \\
\hline TN1 × Latu & $\mathrm{S}$ & 139 & 362 & $1: 3$ & 2.01 & $0.10-0.25$ \\
\hline TN1 $\times$ Minh-Soc & $\mathrm{S}$ & 145 & 427 & $1: 3$ & 0.04 & $0.75-0.90$ \\
\hline TN1 $\times$ Trang Chum & $\mathrm{R}$ & 127 & 41 & $3: 1$ & 0.03 & $0.75-0.90$ \\
\hline TN1 × Ba Kieu & $\mathrm{R}$ & 245 & 67 & $3: 1$ & 2.07 & $0.10-0.25$ \\
\hline TN1 × Nep Bha Bong To & $\mathrm{S}$ & 96 & 347 & $1: 3$ & 2.62 & $0.05-0.10$ \\
\hline
\end{tabular}

${ }^{\mathrm{a}} \mathrm{R}=$ resistant and $\mathrm{S}=$ susceptible.

TABLE 4. Reaction of $\mathrm{F}_{1}$ hybrids and $\mathrm{F}_{2}$ populations to race 2 of Xanthomonas oryzae pv. oryzae from crosses of group 2 cultivars with susceptible cv. TN1

\begin{tabular}{|c|c|c|c|c|c|c|}
\hline \multirow[b]{3}{*}{ Cross } & \multicolumn{6}{|c|}{ Reaction to race $2^{\mathrm{a}}$} \\
\hline & \multirow[b]{2}{*}{$\mathrm{F}_{1}$ plants } & \multicolumn{5}{|c|}{$\mathrm{F}_{2}$ population } \\
\hline & & $\mathrm{R}$ & $\mathrm{S}$ & Ratio & $\chi^{2}$ & $P$ value \\
\hline $\mathrm{TN} 1 \times \mathrm{SLO} 2$ & $\mathrm{R}$ & 137 & 47 & $3: 1$ & 0.03 & $0.80-0.90$ \\
\hline TN1 $\times$ Aghanisail & $\mathrm{R}$ & 117 & 34 & $3: 1$ & 0.50 & $0.25-0.50$ \\
\hline TN1 $\times$ Huson Dhaw & $\mathrm{R}$ & 384 & 148 & $3: 1$ & 2.25 & $0.10-0.25$ \\
\hline TN1 $\times$ Pelatie & $\mathrm{R}$ & 285 & 87 & $3: 1$ & 0.52 & $0.25-0.50$ \\
\hline TN1 × Bhua Balam & $\mathrm{R}$ & 315 & 104 & $3: 1$ & 0.007 & $0.90-0.95$ \\
\hline TN1 $\times$ Kachanchari & $\mathrm{R}$ & 437 & 157 & $3: 1$ & 0.65 & $0.25-0.50$ \\
\hline TN1 $\times$ Surma Sail & $\mathrm{R}$ & 265 & 86 & $3: 1$ & 0.05 & $0.75-0.90$ \\
\hline TN1 $\times$ Khar Mao & $\mathrm{R}$ & 147 & 54 & $3: 1$ & 0.37 & $0.50-0.75$ \\
\hline TN1 × Ganga Sagar & $\mathrm{R}$ & 321 & 109 & $3: 1$ & 0.03 & $0.80-0.90$ \\
\hline TN1 × Arai Raj & $\mathrm{R}$ & 227 & 57 & $3: 1$ & 3.68 & $0.05-0.10$ \\
\hline TN1 × Lota Sail & $\mathrm{S}$ & 75 & 280 & $1: 3$ & 2.84 & $0.05-0.10$ \\
\hline
\end{tabular}

${ }^{\mathrm{a}} \mathrm{R}=$ resistant and $\mathrm{S}=$ susceptible.

TABLE 5. Reaction of $\mathrm{F}_{1}$ hybrids and $\mathrm{F}_{2}$ populations to race 1 of Xanthomonas oryzae pv. oryzae from the crosses of group 1 cultivars with different testers

\begin{tabular}{|c|c|c|c|c|c|c|}
\hline \multirow[b]{3}{*}{ Cross } & \multicolumn{6}{|c|}{ Reaction to race $1^{\mathrm{a}}$} \\
\hline & \multirow[b]{2}{*}{$\mathrm{F}_{1}$ plants } & \multicolumn{5}{|c|}{$\mathrm{F}_{2}$ population } \\
\hline & & $\mathrm{R}$ & $\mathrm{S}$ & Ratio & $\chi^{2}$ & $P$ value \\
\hline IRBB $4 \times$ WC1263 & $\mathrm{R}$ & 504 & 0 & $1: 0$ & 0.0 & 1.00 \\
\hline $\mathrm{IRBB} 4 \times \mathrm{HR} 12$ & $\mathrm{R}$ & 479 & 0 & $1: 0$ & 0.0 & 1.00 \\
\hline $\mathrm{IRBB} 4 \times \mathrm{SLO} 2$ & $\mathrm{R}$ & 493 & 0 & $1: 0$ & 0.0 & 1.00 \\
\hline IRBB4 × Ragu Sail & $\mathrm{R}$ & 487 & 0 & $1: 0$ & 0.0 & 1.00 \\
\hline IRBB5 × Bazail 975 & $\mathrm{R}$ & 485 & 0 & $1: 0$ & 0.0 & 1.00 \\
\hline IRBB5 $\times$ Karia & $\mathrm{R}$ & 472 & 0 & $1: 0$ & 0.0 & 1.00 \\
\hline IRBB5 $\times$ Latu & $\mathrm{R}$ & 314 & 0 & $1: 0$ & 0.0 & 1.00 \\
\hline IRBB8 $\times$ Minh-Soc & $\mathrm{R}$ & 477 & 0 & $1: 0$ & 0.0 & 1.00 \\
\hline IRBB3 $\times$ Trang Chum & $\mathrm{R}$ & 465 & 0 & $1: 0$ & 0.0 & 1.00 \\
\hline IRBB3 × Ba Kieu & $\mathrm{R}$ & 454 & 0 & $1: 0$ & 0.0 & 1.00 \\
\hline IRBB5 $\times$ Nep Bha Bong To & $\mathrm{S}$ & 193 & 277 & $7: 9$ & 1.38 & $0.10-0.25$ \\
\hline IRBB $8 \times$ Nep Bha Bong To & $\mathrm{S}$ & 180 & 295 & $7: 9$ & 6.62 & $<0.05$ \\
\hline
\end{tabular}

${ }^{a} \mathrm{R}=$ resistant and $\mathrm{S}=$ susceptible. 
Designation of new genes. Of the 11 cultivars of group 1,4 (i.e., WC1263, HR 12, SLO 2, and Ragu Sail) were each found to have single dominant genes for resistance that are allelic to $\mathrm{Xa4}$. Bazail 975, Karia, and Latu each have single recessive genes for resistance which are allelic to $x a 5$. Minh-Soc has a single recessive gene for resistance which is allelic to $x a 8$. The recessive gene $x a 8$ was first identified in rice cultivar PI231129 (27). Since then, we have genetically analyzed several hundred cultivars for resistance to bacterial blight and Minh-Soc is the only other cultivar found to have $x a 8$. Trang Chum and $\mathrm{Ba}$ Kieu each have single dominant genes for resistance that are allelic to $\mathrm{Xa3}$. The cultivar Nep Bha Bong To has a recessive gene for resistance that is nonallelic to two other recessive genes, $x a 5$ and $x a 8$. It segregated independently of $x a 5$ but may be linked to $x a 8$ because the $\chi^{2}$ value for independent segregation is quite high. Therefore, the recessive gene for resistance of Nep Bha Bong To appears to be a new gene and, following the rules of gene nomenclature in rice, this gene is designated as $x a 26(t)$.

Eight cultivars of group 2 (i.e., Aghanisail, Huson Dhaw, Pelatie, Bhua Balam, Kanchanchari, Surma Sail, Khar Mao, and Ganga Sagar) each have a single dominant gene allelic to Xa10. In addition, SLO 2 also has Xa10. Although cv. Arai Raj has the reaction pattern to six races that is similar to that of $\mathrm{Xa10}$, it turned out to have a single dominant gene for resistance which is nonallelic to and independent of Xa10 as well as Xa7. This dominant gene for resistance to races 2 and 5 is designated as $\mathrm{Xa27}(t)$.

Similarly, cv. Lota Sail has a reaction pattern to six races that is also similar to that of $\mathrm{Xa10}$. However, it has a single recessive gene for resistance to races 2 and 5 which segregates independently of $x a 5, x a 8$, and Xa10. This gene is designated as $x a 28(t)$.

The genetic analysis of 21 cultivars has resulted in identification of three new genes for resistance to bacterial blight. The genes for resistance of these cultivars are summarized in Table 7.

\section{DISCUSSION}

Insufficient durability of resistance to bacterial blight is a major concern. Durable resistance is "resistance that remains effective while a cultivar possessing it is widely cultivated" (8). Introduction of resistant cultivars often has resulted in shifts of virulence in populations of $X$. oryzae $p v$. oryzae (16). Many cultivars with $\mathrm{X} a 4$ for resistance to bacterial blight have been cultivated widely in the Philippines and elsewhere in Asia. The frequency of pathotypes virulent to $\mathrm{Xa} 4$ increased over time and became dominant in the Philippine populations of the pathogen in response to the use of $\mathrm{Xa} 4$ (18).

One strategy to prolong the useful life of major gene resistance is to pyramid two or more major genes in a single cultivar (10).
This strategy would be desirable if, through various mechanisms (20), it would be more difficult for a pest to overcome several resistance genes in the host than to overcome a single resistance gene.

It is difficult to pyramid resistance genes by phenotypic selection because the presence of one major gene obscures the effects of other genes. Molecular markers that are closely linked to major genes can be used to identify individuals carrying more than one resistance gene in a segregating population. Fortunately, a molecular genetic map of rice densely populated with various types of molecular markers has been prepared (4) and many genes for disease and insect resistance have been tagged with molecular markers (13). Another advantageous situation in regard to bacterial blight is the availability of near-isogenic lines with single genes for resistance (22). DNA marker-aided selection was used to pyramid four bacterial blight resistance genes, Xa4, xa5, xa13, and $\mathrm{Xa21}$. Breeding lines with two, three, and four resistance genes were developed and tested for resistance to bacterial blight. The pyramided lines showed a wider spectrum and a higher level of resistance than lines with only a single gene (5). Pyramided lines were shared with national rice improvement programs of several countries in Asia, where they are being used in local breeding programs (29).

The newly discovered genes are being transferred to near-isogenic background and, at the same time, are being tagged with

TABLE 7. Genes for bacterial blight resistance in the rice cultivars analyzed

\begin{tabular}{lc}
\hline Cultivar & Gene for resistance \\
\hline WC1263 & Xa4 \\
HR 12 & Xa4 \\
SLO 2 & Xa4 + Xa10 \\
Ragu Sail & Xa4 \\
Bazail 975 & $x a 5$ \\
Karia & $x a 5$ \\
Latu & xa5 \\
Minh-Soc & $x a 8$ \\
Trang Chum & Xa3 \\
Ba Kieu & Xa3 \\
Nep Bha Bong To & Xa26(t) \\
Aghanisail & Xa10 \\
Huson Dhaw & Xa10 \\
Pelatie & Xa10 \\
Bhua Balam & Xa10 \\
Kanchanchari & Xa10 \\
Khar Mao & Xa10 \\
Surma Sail & Xa10 \\
Ganga Sagar & Xa10 \\
Arai Raj & Xa27(t) \\
Lota Sail & Xa28(t) \\
\hline
\end{tabular}

TABLE 6. Reaction of $F_{1}$ hybrids and $F_{2}$ populations to race 2 from the crosses of group 2 cultivars with different testers

\begin{tabular}{|c|c|c|c|c|c|c|}
\hline \multirow[b]{3}{*}{$\underline{\text { Cross }}$} & \multicolumn{6}{|c|}{ Reaction to race $2^{\mathrm{a}}$} \\
\hline & \multirow[b]{2}{*}{$\mathrm{F}_{1}$ plants } & \multicolumn{5}{|c|}{$\mathrm{F}_{2}$ population } \\
\hline & & $\mathrm{R}$ & $S$ & Ratio & $\chi^{2}$ & $P$ value \\
\hline IRBB10 $\times$ Aghanisail & $\mathrm{R}$ & 490 & 0 & $1: 0$ & 0.0 & 1.00 \\
\hline IRBB10 $\times$ Huson Dhaw & $\mathrm{R}$ & 377 & 0 & $1: 0$ & 0.0 & 1.00 \\
\hline IRBB10 $\times$ Pelatie & $\mathrm{R}$ & 500 & 0 & 1:0 & 0.0 & 1.00 \\
\hline IRBB10 $\times$ Bhua Balam & $\mathrm{R}$ & 494 & 0 & $1: 0$ & 0.0 & 1.00 \\
\hline IRBB10 $\times$ Khar Mao & $\mathrm{R}$ & 477 & 0 & $1: 0$ & 0.0 & 1.00 \\
\hline IRBB10 $\times$ Ganga Sagar & $\mathrm{R}$ & 479 & 0 & $1: 0$ & 0.0 & 1.00 \\
\hline IRBB10 $\times$ Arai Raj & $\mathrm{R}$ & 437 & 36 & $15: 1$ & 1.50 & $0.10-0.25$ \\
\hline IRBB7 $\times$ Arai Raj & $\mathrm{R}$ & 429 & 20 & $15: 1$ & 2.47 & $0.10-0.25$ \\
\hline IRBB10 × Lota Sail & $\mathrm{R}$ & 348 & 99 & $13: 3$ & $3: 39$ & $0.05-0.10$ \\
\hline IRBB5 $\times$ Lota Sail & $\mathrm{S}$ & 179 & 213 & $7: 9$ & 0.58 & $0.25-0.50$ \\
\hline IRBB $8 \times$ Lota Sail & S & 119 & 170 & $7: 9$ & 0.78 & $0.25-0.50$ \\
\hline
\end{tabular}

${ }^{\mathrm{a}} \mathrm{R}=$ resistant and $\mathrm{S}=$ susceptible. 
molecular markers. Thus, these genes can be employed in rice improvement programs either through conventional breeding approaches or through molecular marker-aided selection or gene pyramiding.

Genetic engineering also allows pyramiding of resistance genes. Resistance genes, if cloned, can be introduced into the rice genome in combination with existing resistance genes or with other novel genes.

As an example, $\mathrm{Xa21}$ was cloned from a near-isogenic rice line, IRBB21, by Song et al. (30). It was introduced into IR72, which has $\mathrm{Xa} 4$ for resistance (31). Thus, transgenic IR72 has Xa4 and $X a 21$ pyramided together. This pyramided line has been evaluated under field conditions in China and showed a broad spectrum of resistance.

To date, 49,752 entries from the germ plasm collection maintained at IRRI have been evaluated for resistance to bacterial blight and $11.1 \%$ were found to be resistant (6). Approximately 700 have been genetically analyzed and this has resulted in the identification of 21 genes for resistance. Three genes (xa19, xa20, and $X a 25$ ) have been induced through mutagenesis. Two dominant genes, $X a 21$ and $X a 23$, were transferred to cultivated germ plasm from closely related wild species Oryza longistaminata and $O$. rufipogon, respectively. Most of the distantly related wild species are resistant to bacterial blight. Crosses between these wild species and cultivated rice have been accomplished through embryo rescue technique (7) and genes for bacterial blight resistance have been transferred to cultivated rice (1).

Two bacterial blight resistance genes have been cloned. Xa21 was isolated by map-based cloning and found to be member of a complex locus located on chromosome 11 (30). As mentioned earlier, this gene has been transferred back to rice through genetic engineering. $\mathrm{Xal}$, the second resistance gene cloned from rice, is located on chromosome 4 (33). Unlike $\mathrm{Xa21}$, Xal is a single-copy gene and is pathogen and wound inducible.

The concept of tissue-specific expression of major genes could be applied not only to genes isolated from other organisms but also to the manipulations of natural resistance genes such as $\mathrm{Xal}$ and $\mathrm{Xa21}$. When cloned major genes are engineered for tissuespecific expression, there will be less selection pressure on the pathogen exerted by the major genes. If the major genes for bacterial resistance could be engineered for expression in the leaves from booting stage until 10 to 15 days after flowering, their expression probably could protect the crop from yield losses and would be more durable.

As discussed above, various genetic strategies for reducing the yield losses from bacterial blight include identification of genes for resistance from the primary gene pool, transfer of genes for resistance from the closely as well as distantly related germ plasm, mapping and tagging of genes with molecular markers, transfer of genes to the elite genetic background through conventional and molecular marker-aided selection, pyramiding of genes through molecular marker-aided selection, fine mapping and cloning of genes for resistance, introduction of cloned genes through transformation into elite cultivars under tissue-specific expression, and pyramiding the cloned genes with naturally occurring genes. The identification of new resistance genes reported in this study is thus a basic step in the galaxy of approaches to minimize the losses caused by $X$. oryzae $p v$. oryzae in rice.

\section{LITERATURE CITED}

1. Amante-Bordeos, A., Sitch, L. A., Nelson, R., Dalmacio, R. D., Aswindinoor, H., and Leung, H. 1992. Transfer of bacterial blight and blast resistance from the tetraploid wild rice, Oryza minuta to cultivated rice, Oryza sativa. Theor. Appl. Genet. 84:345-354.

2. Ezuka, A., Horino, O., Toriyama, K., Shinoda, H., and Morinaka, T. 1975. Inheritance of resistance of rice variety Wase Aikoku 3 to Xanthomonas oryzae. Bull. Tokai-kinki Nat. Agric. Exp. Stn. 28:124130.
3. Gao, D. Y., Xu, Z. G., Chen, Z. Y., Sun, L. H., Sun, Q. M., Lu, F., Hu, B. S., Liu, Y. F., and Tang, L. H. 2001. Identification of a new gene for resistance to bacterial blight in a somaclonal mutant HX-3 (indica). Rice Genet. Newsl. 18:66-68.

4. Harushima, Y., Yano, M., Shomura, A., Sato, M., Shimano, T., Kuboki, Y., Yamamoto, T., Lin, S. Y., Antonio, B. A., Parco, A., Kajiya, H., Huang, N., Yamamoto, K., Nagamura, Y., Kurata, N., Khush, G. S., and Sasaki, T. 1998. A high-density rice genetic linkage map with 2275 markers using a single $\mathrm{F}_{2}$ population. Genetics 148:479-494.

5. Huang, N., Angeles, E. R., Domingo, J., Magpantay, G., Singh, S., Zhang, G., Kumaradivel, N., Bennett, J., and Khush, G. S. 1997. Pyramiding of bacterial blight resistance genes in rice: Marker-aided selection using RFLP and PCR. Theor. Appl. Genet. 95:313-320.

6. Jackson, M. T. 1997. Conservation of rice genetic resources: The role of the International Rice Genebank at IRRI. Plant Mol. Biol. 35:61-67.

7. Jena, K. K., and Khush, G. S. 1990. Introgression of genes from Oryza officinalis Well ex Watt to cultivated rice, O. sativa L. Theor. Appl. Genet. 80:737-745.

8. Johnson, R. 1981. Durable resistance: Definition of genetic control and attainment in plant breeding. Phytopathology 71:567-568.

9. Kauffman, H. E., Reddy, A. P. K., Hsieh, S. P. Y., and Merca, S. D. 1973. An improved technique for evaluating resistance of rice varieties to Xanthomonas oryzae. Plant Dis. Rep. 57:537-541.

10. Khush, G. S. 1976. Breeding for resistance in rice. In the genetic basis of epidemics in agriculture. Ann. N. Y. Acad. Sci. 287:296-308.

11. Khush, G. S., and Angeles, E. R. 1999. A new gene for resistance to race 6 of bacterial blight in rice, Oryza sativa L. Rice Genet. Newsl. 16:9293.

12. Khush, G. S., Bacalangco, E., and Ogawa, T. 1990. A new gene for resistance to bacterial blight from $O$. Longistaminata. Rice Genet. Newsl. 7:121-122.

13. Khush, G. S., and Brar, D. S. 2001. Rice genetics from Mendel to functional genomics. Pages 3-25 in: Rice Genetics IV. G. S. Khush, D. S. Brar, and B. Hardy, eds. Science Publishers, New Delhi and International Rice Research Institute, Los Baños, Philippines.

14. Khush G. S., Mackill, D. J., and Sidhu, G. S. 1989. Breeding rice for resistance to bacterial blight. Pages 207-217 in: Bacterial Blight of Rice. International Rice Research Institute, Manila, Philippines.

15. Lin, X. H., Zhang, D. P., Xie, Y. F., Gao, H. P., and Zhang, Q. 1996. Identifying and mapping a new gene for bacterial blight resistance in rice based on RFLP markers. Phytopathology 86:1156-1159.

16. Mew, T. W. 1987. Current status and future prospects of research on bacterial blight of rice. Annu. Rev. Phytopathol. 25:359-382.

17. Mew, T. W., and Vera Cruz, C. M. 1979. Variability of Xanthomonas oryzae: Specificity in infection of rice differentials. Phytopathology 69:152-155.

18. Mew, T. W., and Vera Cruz, C. M. 1985. Virulence of Xanthomonas campestris pv. Oryzae in the Philippines. (Abstr.) Phytopathology 75:1316.

19. Mew, T. W., Vera Cruz, C. M., and Medalla, E. S. 1992. Changes in race frequency of Xanthomonas oryzae pv. oryzae in response to rice cultivars planted in Philippines. Plant Dis. 76:1029-1032.

20. Mundt, C. C. 1990. Probability of mutation to multiple virulence and durability of resistance gene pyramids. Phytopathology 80:221-223.

21. Nelson, R. J., Baraoidan, M. R., Vera Cruz, C. M., Yap, I. V., Leach, J. E., Mew, T. W., and Leung, H. 1994. Relationship between phylogeny and pathotype for the bacterial blight pathogen of rice. Appl. Environ. Microbiol. 60:3275-3283.

22. Ogawa, T., Yamamoto, T., Khush, G. S., and Mew, T. W. 1991. Breeding of near-isogenic lines of rice with single genes for resistance to bacterial blight pathogen (Xanthomonas campestris pv. oryzae). Jpn. J. Breed. 41:523-529.

23. Olufowote, J. O., Khush, G. S., and Kauffman, H. E. 1977. Inheritance of bacterial blight resistance in rice. Phytopathology 67:772-775.

24. Ou, S. H. 1985. Rice Diseases. Commonwealth Mycological Institute Kew, Survey, England.

25. Petpisit, V., Khush, G. S., and Kauffman, H. E. 1977. Inheritance of resistance to bacterial blight in rice. Crop Sci. 17:551-554.

26. Sakaguchi, S. 1967. Linkage studies on the resistance to bacterial leaf blight, Xanthomonas oryzae (Uyeda et Ishiyama) Dowson, in rice. Bull. Nat. Inst. Agric. Sci. Jpn. Ser. D. 16:1-18.

27. Sidhu, G. S., Khush, G. S., and Mew, T. W. 1978. Genetic analysis of bacterial blight resistance in seventy-four cultivars of rice, Oryza sativa L. Theor. Appl. Genet. 53:105-111.

28. Singh, G. P., Srivastaba, M. K., Singh, R. V., and Singh, R. M. 1977. Variation and qualitative losses caused by bacterial blight in different rice varieties. Indian Phytopathol. 30:180-185.

29. Singh, S., Sidhu, J. S., Huang, N., Vikal, Y., Li, Z., Brar, D. S., Dhaliwal, H. S., and Khush, G. S. 2001. Pyramiding three bacterial blight 
resistance genes $(x a 5, x a 13$, and $\mathrm{Xa21})$ using marker-assisted selection into indica rice cultivar PR106. Theor. Appl. Genet. 102:1011-1015.

30. Song, W. Y., Wang, G. L., Chen, L. L., Kim, H. S., Pi, L. Y., Gardner, J., Wang, B., Holsten, J., Thai, W. X., Zhu, L. H., Fauquet, C., and Ronald, P. C. 1995. A receptor kinase-like protein encoded by the rice disease resistance gene Xa21. Science 270:1804-1806.

31. Tu, J., Ona, I., Zhang, Q., Mew, T. W., Khush, G. S., and Datta, S. K. 1998. Transgenic rice variety IR72 with $\mathrm{Xa21}$ is resistant to bacterial blight. Theor. Appl. Genet. 97:31-36.

32. Vera Cruz, C. M., and Mew, T. W. 1989. How variable is Xanthomonas campestris pv. Oryzae? Pages 153-166 in: Bacterial Blight of Rice. International Rice Research Institute, Manila, Philippines.

33. Yoshimura, S., Yamanouchi, U., Katayose, Y., Toki, S., Wang, Z. X., Kono, I., Kurata, N., Yano, M., Iwata, N., and Sasaki, T. 1998. Expression of $\mathrm{Xal}$, a bacterial blight resistance gene in rice, is induced by bacterial inoculation. Proc. Natl. Acad. Sci. USA 95:1663-1668.

34. Zhang, Q., Lin, S. C., Zho, B. Y., Wang, C. L., Yang, W. C., Zhou, Y. L., Li, D. Y., Chen, C. B., and Zhu, L. H. 1998. Identification and tagging a new gene for resistance to bacterial blight (Xanthomonas oryzae pv. oryzae) from O. rufipogon. Rice Genet. Newsl. 15:138-142. 